\title{
Factors Influencing the Attitude of Return Migrated Rural Youths towards Agripreneurship Development
}

\author{
J. Parameswaranaik* \\ Central Sericultural Research and Training Institute, Berhampore, West Bengal, India \\ *Corresponding author
}

\section{A B S T R A C T}

\section{Keywords}

Agripreneurship,

Factors, Return

Migration, Rural

youths and South India

Article Info

Accepted:

26 June 2019

Available Online:

10 July 2019
Return migration is the gauge for changing socio-economic and political conditions in rural areas. Return migrated rural youths have involved themselves in agripreneurship development in rural areas. Here, the attitude of youths towards agripreneurship plays a critical role hence the study was taken with 180 return migrated rural youths in three selected states of southern India. The salient findings were the majority of the respondents $(52.23 \%)$ possessed a moderately favourable attitude. The factors influencing the attitude of youths were land-holding, herd-size and risk-orientation had a positive and significant relationship at one percent level of probability. The extent of contribution of independent variables with the dependent variable was worked out while using multiple regression analysis, the $\mathrm{R}^{2}$ value was 0.646 , which revealed that 64.60 percent variation in the attitude of return migrated rural youth towards agripreneurship development was explained by ten independent variables selected for the study. I have more opportunities to work as per my own decisions was a top-ranked statement (with 90.50 weighed mean score percentage). Whereas low social recognition is one of the important issues which hinders the youth's involvement in agripreneurship. Hence Promotion and recognition of progressive return migrated rural youths in agripreneurship would motivate them to involve more dynamically in agripreneurship development. This can ignite the return migration process and promote agripreneurship among such rural youths.

\section{Introduction}

The youth shows strong passion, motivation, and willpower which make them the most valuable human resource for fostering economic, cultural and political development of a nation. Nearly 30 crores of nation's youth reside in rural areas (CSO 2017). Young women and men living in rural areas face challenges brought about by limited and unequal access to resources, healthcare, education, training, and employment. They are the major seekers of employment as they traverse their journey of life from adolescent to youth. If they didn't find a suitable opportunity in their locality of residence, then the chance of migration to other places is a common phenomenon in rural areas.

Migration is a major demographic process that has been an integral and salient feature of human history since time immemorial. It is the 
geographic movement of people across a specified boundary for the purpose of establishing a new permanent or semipermanent residence. It is a sign of wide disparities in economic and social conditions between the origin and destination places (Rogaly et al., 2001). But in recent days' those people who got migrated are coming back to their place of origin can be stated as return migration (Parameswaranaik et al., 2018).

It is defined as the "voluntary movement of migrants back to their place of origin". (Rajan, 2013) Return to the home destination is part of the migration strategy (Smoliner et al., 2012). It is the logical consequences of the successful achievement of all migration-related goals and targets. Return migration is becoming a very common phenomenon in rural areas (Parameswaranaik et al., 2018).

Since rural youths' return migration reflects considerable changes in the structural and functional system of rural areas (NSSO 2010). When they returned to their place of origin (rural areas) they may not have much an alternative to take up as an occupation other than agriculture and allied activities for their livelihood. Here, the attitude of youths towards agripreneurship plays a critical role; and which in the long run, could determine the future of Indian agriculture. Under this basic tent the present study entitled as 'Attitude of return migrated rural youths towards agripreneurship development" was formulated and also efforts were made to analyse the factors influencing the attitude of return migrated rural youths towards agripreneurship development were documented.

\section{Materials and Methods}

For the present study 180 return migrated rural youths were purposively selected from southern India i.e., Karnataka, Tamil Nadu, and Kerala States. Respondents for the study were aged between 18 to 35 years, who primarily left their villages to urban areas for doing non-agricultural activities as an occupation; and stayed there for a minimum of two years, and subsequently returned to their villages to carry out agriculture and/or any enterprises related to agriculture and allied sectors, to earn his/her livelihood.

Attitude means a set of tendencies, views, and beliefs of an individual about his/her environmental factors. This tendency and belief will be stabilized based on the environmental effect, the gained experiences and the period of time (Rafiepour, 1993). Usually, attitude portrays either a positive or negative view towards a person/place/thing. In this study, the attitude was operationalized as the psychological disposition of the rural youths towards agripreneurship in varying degrees of favourableness or unfavourableness.

Attitude of return migrated rural youths towards agripreneurship development was measured by a separate scale developed for this purpose. The scale was "Attitude of return migrated rural youths towards agripreneurship development". This was developed by following the method suggested by Likert (1932). Broadly, six-step procedures were followed for the construction of scale, which were as follows:

\section{Defining construct}

Item collection, development and scrutiny of items

Item analysis by calculating t-statistic

Reliability analysis

Validity testing

Final selection of items 
Items were selected based on higher t-value over a cut-off point, wherein the t-value were be greater than or equal to 1.75 for final inclusion of items in the scale as suggested by Edward (1969).

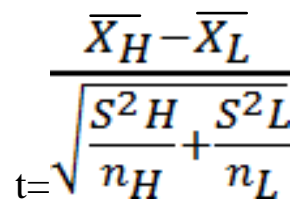

Where,

$\overline{X_{H}}=$ Mean score of a given statement for the high group

$\overline{X_{L}}=$ Mean score of a same statement for the low group

$S^{2} H=$ The variance of the distribution of responses of the high group to the statement

$S^{2} L=$ The variance of the distribution of responses of the low group to the statement

$n_{H}=$ The number of subjects in the high group

$n_{L}=$ The number of subjects to the low group

The final scale consisted of 14 statements; of which, 8 statements were positive and 6 statements were negative.

\section{Results and Discussion}

Cumulative Frequency method was employed to categorize the respondents into three groups' viz., less favourable, moderately favourable and highly favourable, based on their expressions of attitude.

The data on distribution of return migrant rural youth based on their attitude towards agripreneurship have been presented in Table 1.
According to the table 1 , it is clearly evident that the majority of the respondents $(52.23 \%)$ possessed a moderately favourable attitude towards agripreneurship development. This is may be due to their new experience in farming, adroitness in farm management and their family's psychological outlook regarding their continuance in agriculture could have stirred their personal commitment to agriculture, also youths were felt responsible to take decision by themselves, and there was no pressure on them, from a higher level like previous job they were doing in urban area. It is also proved by King (1978), Dustmann (2001) and Cassarino (2004). Accordingly, 30.55 percent and 17.22 percent of the respondents were possessed highly favourable and unfavourable attitude towards agripreneurship development respectively. The unfavourable attitude may be due to the fact that some of the youths wanted to quit farming, because of the reasons like less profitability, dissatisfaction, low respect given by society, etc. further they are planning to migrate to gulf countries (Specially in case of Kerala). The moderately and highly favourable attitude of return migrated rural youths towards agripreneurship development might have made the rural youths to continue practicing agripreneurship.

Analysis was carried out with the weighted mean technique to provide a rank to each attitude statement (Table 2). The statement "now, I have more opportunities to work as per my own decisions" is a top-ranked statement (with 90.50 weighed mean score percentage); it may due to the reason of respondents previously working under someone in an urban area, while following orders from his/her higher authority employer; but now, they got a chance to work as per their own decisions and it made them have a favourable attitude towards agripreneurship development. The statement "my interpersonal communication with the people of 
the community is increasing after taking up agripreneurship" was given second rank (with 82.50 weighted mean score percentage), which may be linked with the reason that, after returning from the urban area, youths had got themselves involved in society/community actions, village festivals and etc., hence their inter-personal communication with the people of the community had increased. Majority of youths were their decision to go for agripreneurship (81.00 WMS). And, with respect to the negative statements of attitude, it was found that the statement "Agripreneurship is for uneducated and poor people only." emerged as an eleventh ranked statement, because youths felt that agripreneurship was an activity which could be carried out by both educated and uneducated persons. Further, the statement "I would prefer to work under someone to get an assured income rather than practicing agripreneurship" was observed to be the lastranked statement (with 30.05 weighed mean score percentage), as the rural youths were found to be intended to work as per their own decision rather than working under someone else's orders/instructions.

Youths were having favourable attitude towards agripreneurship development as they are providing employment to others through agripreneurship and now they feel their previous job was meaningless and it's worthwhile to take up agripreneurship, as it leads towards prosperity, it proves that they have completely involved themselves in agriculture and allied activities.

Association and contribution of profile characteristics of respondents with their attitude towards agripreneurship development

The association and contribution of profile characteristics of return migrated rural youths with their attitude towards agripreneurship development has been analyzed. The results revealed that the variables like land-holding, herd-size, and risk- orientation had a positive and significant relationship at one percent level of probability; whereas marital status, education, and annual income portrayed negative but significant relationship at the five percent level of probability. However, variables, such as sex, family size, milk production, and mass media exposure depicted a non-significant relationship with the dependent variable. The extent of contribution of independent variables with the dependent variable was worked out while using multiple regression analysis and the results have been presented. Hence table 3 indicated that the $\mathrm{R}^{2}$ value was 0.646 , which revealed that 64.60 percent variation in the attitude of return migrated rural youth towards agripreneurship development was explained by ten independent variables selected for the study. The ' $F$ ' value (6.642) was significant at one percent level of probability. The prediction equation was fitted in as below:

Table.1 Distribution of respondents based on their attitude towards agriprenuership development

\begin{tabular}{|c|c|c|c|c|c|c|c|c|c|}
\hline \multirow[t]{2}{*}{ S.N } & \multirow[t]{2}{*}{ Category } & \multicolumn{2}{|c|}{ Tamil Nadu } & \multicolumn{2}{|c|}{ Karnataka } & \multicolumn{2}{|c|}{ Kerala } & \multicolumn{2}{|c|}{ Total } \\
\hline & & No & $\%$ & No & $\%$ & No & $\%$ & No & $\%$ \\
\hline 1 & Less favourable & 18 & 30.00 & 20 & 33.33 & 17 & 28.33 & 55 & 30.55 \\
\hline 2 & $\begin{array}{l}\text { Moderately } \\
\text { favourable }\end{array}$ & 36 & 60.00 & 31 & 51.67 & 27 & 45.00 & 94 & 52.23 \\
\hline 3 & Highly favourable & 6 & 10.00 & 9 & 15.00 & 16 & 26.67 & 31 & 17.22 \\
\hline & Total & 60 & 100 & 60 & 100 & 60 & 100 & 180 & 100 \\
\hline
\end{tabular}


Table.2 Distribution of respondents based on their attitude towards agriprenuership development

\begin{tabular}{|c|c|c|c|}
\hline S.N & Statements & WMS\% & RANK \\
\hline 1 & Now, I have more opportunities to work as per my own decisions. & 90.50 & I \\
\hline 2 & $\begin{array}{l}\text { My inter-personal communication with the people of the community is increasing after taking up } \\
\text { agripreneurship. }\end{array}$ & 82.50 & II \\
\hline 3 & I am happy with my decision to go for agripreneurship. & 81.00 & III \\
\hline 4 & No standardized knowledge is required to take up agripreneurship. & 78.65 & IV \\
\hline 5 & One should be proud of being an Agripreneur. & 76.50 & $\mathbf{V}$ \\
\hline 6 & Agripreneurship gives me the feelings of accomplishment and pride. & 74.00 & VI \\
\hline 7 & Through agripreneurship, I can provide employment to others. & 71.35 & VII \\
\hline 8 & After getting into agripreneurship, I sometimes feel that my previous job was meaningless. & 68.65 & VIII \\
\hline 9 & $\begin{array}{l}\text { Only those people, who are unable to go for any other work, get themselves involved in } \\
\text { agripreneurship. }\end{array}$ & 66.50 & IX \\
\hline 10 & It is worthwhile to take up agripreneurship, as it may lead towards prosperity. & 52.00 & $\mathbf{X}$ \\
\hline 11 & Agripreneurship is for uneducated and poor people only. & 45.86 & $\mathbf{X I}$ \\
\hline 12 & Agripreneurship is not viable for a youth like me. & 40.50 & XII \\
\hline 13 & I regret getting involved in agripreneurship. & 38.50 & XIII \\
\hline 14 & I would prefer to work under someone to get assured income rather than practicing agripreneurship. & 33.05 & XIV \\
\hline
\end{tabular}


Table.3 Association and contribution of profile characteristics of return migrated rural youths with their attitude towards agripreneurship development

\begin{tabular}{|c|c|c|c|c|c|c|c|c|c|c|c|c|c|c|c|c|c|}
\hline \multirow{2}{*}{$\begin{array}{l}\mathbf{S} . \\
\mathbf{N}\end{array}$} & \multirow{2}{*}{$\begin{array}{c}\text { Profile } \\
\text { characteristics }\end{array}$} & \multicolumn{4}{|c|}{ Tamil Nadu } & \multicolumn{4}{|c|}{ Karnataka } & \multicolumn{4}{|c|}{ Kerala } & \multicolumn{4}{|c|}{ Total Respondents } \\
\hline & & $\begin{array}{c}\text { 'r' } \\
\text { value }\end{array}$ & PRC & SE & $\begin{array}{c}\text { 't' } \\
\text { value }\end{array}$ & $\begin{array}{c}\text { 'r' } \\
\text { value }\end{array}$ & PRC & SE & $\begin{array}{c}\text { 't' } \\
\text { value }\end{array}$ & $\begin{array}{c}\text { 'r' } \\
\text { value }\end{array}$ & PRC & SE & $\begin{array}{c}\text { 't' } \\
\text { value }\end{array}$ & $\begin{array}{c}\text { 'r' } \\
\text { value }\end{array}$ & PRC & SE & 't' value \\
\hline 1 & $\left(\mathbf{X}_{1}\right) \operatorname{Sex}$ & $\begin{array}{c}- \\
0.361 * *\end{array}$ & 0.610 & 1.422 & 0.429 & $0.230^{-}$ & $\begin{array}{c}- \\
1.426\end{array}$ & 1.009 & $\overline{-}^{-}$ & -0.348 & $\overline{-}$ & 0.528 & $0.284^{\mathrm{NS}}$ & $\overline{-}^{-}$ & $\overline{-}-$ & 0.707 & $-0.937^{\mathrm{NS}}$ \\
\hline 2 & $\begin{array}{l}\left(\mathbf{X}_{2}\right) \quad \text { Marital } \\
\text { Status }\end{array}$ & $-{ }^{-}$ & $\begin{array}{c}- \\
1.062\end{array}$ & 0.876 & $\begin{array}{c}- \\
2.910^{* *}\end{array}$ & -0.272 & 0.809 & 0.744 & $1.087^{\mathrm{NS}}$ & $\begin{array}{l}0.540 * \\
*\end{array}$ & - & 0.377 & $\overline{-}^{-}-023^{\mathrm{NS}}$ & $-{ }^{-}$ & $\begin{array}{c}- \\
1.062\end{array}$ & 0.519 & $-2.048 *$ \\
\hline 3 & $\left(\mathbf{X}_{3}\right)$ Education & $0.031^{\mathrm{NS}}$ & 2.964 & 1.931 & -1.535 & $\begin{array}{c}0.588^{*} \\
*\end{array}$ & 5.408 & 1.802 & $3.001 * *$ & $\begin{array}{c}0.628^{*} \\
*\end{array}$ & 1.413 & 0.655 & $2.657 * *$ & $-{ }^{-}$ & 2.063 & 0.910 & $-2.267 *$ \\
\hline 4 & $\begin{array}{l}\left(\mathbf{X}_{4}\right) \text { Family } \\
\text { Size }\end{array}$ & $0.098^{\mathrm{NS}}$ & 3.791 & 1.200 & 3.158 & $-{ }^{-}$ & $\begin{array}{c}- \\
0.618\end{array}$ & 1.147 & $0.538^{\mathrm{NS}}$ & $\begin{array}{c}0.588^{*} \\
*\end{array}$ & 5.408 & 1.802 & $3.001 * *$ & $0.053^{\mathrm{NS}}$ & 0.438 & 0.194 & $0.257^{\mathrm{NS}}$ \\
\hline 5 & $\begin{array}{l}\left(\mathbf{X}_{5}\right) \text { Land } \\
\text { holding }\end{array}$ & $0.465^{* *}$ & 0.073 & 0.335 & $0.217^{\mathrm{NS}}$ & 0.618 & 1.312 & 0.533 & $2.462 * *$ & $\begin{array}{c}0.499 * \\
*\end{array}$ & 0.191 & 0.203 & $0.944^{\mathrm{NS}}$ & $0.588 * *$ & 0.529 & $\begin{array}{c}0 . \\
249\end{array}$ & $3.216 * *$ \\
\hline 6 & $\left(\mathbf{X}_{\mathbf{6}}\right)$ Herd Size & $0.285^{*}$ & 0.126 & 0.221 & $0.571^{\mathrm{ns}}$ & $\begin{array}{c}0.507 * \\
*\end{array}$ & $\begin{array}{c}- \\
0.564\end{array}$ & 0.329 & $1.714^{-}$ & - & 2.630 & 0.940 & $-2.203^{*}$ & $0.468 * *$ & 2.365 & 1.425 & $2.184 * *$ \\
\hline 7 & $\begin{array}{l}\left(\mathbf{X}_{7}\right) \text { Milk } \\
\text { Production }\end{array}$ & $0.053^{\mathrm{NS}}$ & 0.438 & 0.194 & 0.0257 & -0.272 & 0.809 & 0.744 & $1.087^{\mathrm{NS}}$ & -0.348 & $\begin{array}{c}- \\
0.150\end{array}$ & 0.528 & $0.284^{\mathrm{NS}}$ & -0.272 & 0.809 & 0.744 & $1.087^{\mathrm{NS}}$ \\
\hline 8 & $\begin{array}{l}\left(\mathbf{X}_{\mathbf{8}}\right) \text { Annual } \\
\text { Income }\end{array}$ & $\begin{array}{c}- \\
0.364 * *\end{array}$ & 0.759 & 0.344 & $0.205^{*}$ & $\begin{array}{c}0.364 * \\
*\end{array}$ & 0.759 & 0.344 & $2.205^{*}$ & $\begin{array}{c}- \\
0.361 *\end{array}$ & 0.610 & 1.522 & $\begin{array}{l}0.429 \mathrm{~N} \\
\mathrm{~S}\end{array}$ & $0.324 * *$ & $\begin{array}{c}- \\
1.062\end{array}$ & 0.876 & $-2.310 *$ \\
\hline 9 & $\begin{array}{l}\left(\mathbf{X}_{\mathbf{g}}\right) \text { Risk } \\
\text { Orientation }\end{array}$ & $-\overline{-}^{-}$ & 6.394 & 2.197 & $2.910^{-}$ & $\begin{array}{c}0.543 * \\
*\end{array}$ & 0.742 & 0.364 & $2.041 *$ & $-\overline{-}^{-}$ & $6 . \overline{-}$ & 2.194 & $2.910^{* *}$ & 0.618 & 1.312 & 0.533 & $2.462 * *$ \\
\hline 10 & $\begin{array}{l}\left(\mathbf{X}_{10}\right) \\
\text { Mass media } \\
\text { Exposure }\end{array}$ & $0.365^{* *}$ & 0.933 & 0.351 & $2.661 * *$ & $0.098^{\mathrm{N}}$ & 3.791 & 1.200 & $3.158 * *$ & 0.093 & 0.289 & 0.175 & $14.651^{N}$ & $0.465 * *$ & 0.073 & 0.335 & $0.217^{\mathrm{NS}}$ \\
\hline & $\begin{array}{c}\mathbf{R}^{2} \\
\text { F value }\end{array}$ & \multirow{2}{*}{\multicolumn{4}{|c|}{$\begin{array}{c}0.589 \\
6.141^{* *} \\
1.354\end{array}$}} & \multirow{2}{*}{\multicolumn{4}{|c|}{$\begin{array}{c}0.746 \\
10.642 * * \\
2.185\end{array}$}} & \multirow{2}{*}{\multicolumn{4}{|c|}{$\begin{array}{c}0.544 \\
8.648^{* *} \\
17.368\end{array}$}} & \multirow{2}{*}{\multicolumn{4}{|c|}{$\begin{array}{c}0.646 \\
6.642 * * \\
12.185\end{array}$}} \\
\hline & Constant & & & & & & & & & & & & & & & & \\
\hline & $\begin{array}{l}\mathrm{PR} \\
\mathrm{SE}= \\
* *=\end{array}$ & $\begin{array}{l}=\text { Partial R } \\
\text { Standard } \\
\text { Significan }\end{array}$ & $\begin{array}{l}\text { egressior } \\
\text { rror } \\
\text { at } 0.01\end{array}$ & Co-effi & & & & $=$ Nor & nificant & & & & & & & & \\
\hline
\end{tabular}


$\mathrm{Y}_{1}=12.185-0.663\left(\mathrm{X}_{1}\right)-1.062\left(\mathrm{X}_{2}\right)-$ $2.063\left(\mathrm{X}_{3}\right)+0.438\left(\mathrm{X}_{4}\right)+0.529\left(\mathrm{X}_{5}\right)+$ $2.365\left(\mathrm{X}_{6}\right)+0.809\left(\mathrm{X}_{7}\right)-1.062\left(\mathrm{X}_{8}\right)+$ $1.312\left(\mathrm{X}_{9}\right)+0.073\left(\mathrm{X}_{10}\right)$

It could be observed from the table that among five significantly contributing variables, land-holding and risk-orientation were found to contribute much on 'attitude of return migrated rural youths towards agripreneurship development'. In general, land-holding would enhance a favourable mindset towards agripreneurship development. The more the possession of risk-orientation more would be the dexterity to manage the agripreneurship, and this would lead to possession of a positive attitude towards agripreneurship development.

Overall, the contribution as well as the relationship of the profile characteristics of the return migrated rural youth with their attitude towards agripreneurship revealed that land-holding, herd-size, and risk-orientation favourable attitude towards agripreneurship development.

The findings of Sajjan (2006) and Anamica (2013) were found to be different, wherein variables like educational status, annual income, land-holding, and mass media exposure of the respondents positively favoured the attitude of rural youth towards agriculture.

Rural youths happen to be a formidable force in the agricultural sector. They constitute a sizable proportion of future progressive farmers. On the basis of the findings of the study and aforesaid discussions as related to the present study, it may be concluded that the majority possessed a moderately favourable attitude towards agripreneurship development. Hence there is a need to form proper extension interventions to focus return migrants. Promotion and recognition of progressive return rural youths in agriculture and allied sectors would also motivate them to involve more dynamically in agripreneurship development. The economic dimension of agripreneurship has been the key influencing factor to determine the attitude of youths, hence the research and development system should develop economically-profitable, environment-friendly and sustainable kinds of successful agripreneurship models which can pave the way to motivate the return migrated rural youths to adopt such models into practical usage. This can ignite the return migration process and promote agripreneurship among such rural youths.

\section{References}

Anamica, M (2013). Migration of Rural Youth-An Analysis, PhD, Thesis (unpub.). Tamil Nadu Agricultural University.

Cassarino, J. (2004). Theorizing Return Migration - The conceptual Approach to return migration revisited. International journal of multicultural societies, Vol 6, No 2 pp 253-257.

Central Statistics Office (2017) YOUTH IN INDIA, Ministry of Statistics and Programme

Dustmann, C. (2001). Why GO Back? Return Motives for Migrant workers. Routledge Contemporary Economic Policy Issues, London.

Likert, R. (1932). A Technique for the Measurement of Attitudes. Archives of Psychology. 140, 1-55.

National Sample Survey Office (2010): "Migration in India", Report No 470 (55/10/8), 1999-2000 (Ministry of Statistics and Programme Implementation, New Delhi).

Parameswaranaik $\mathbf{J}$ and Sujeet Kumar Jha, 2018. Return Migration of Rural Youth: A New Trend in Rural India. Journal of Global Communication. Vol. 11, No. 2, pp. 124-127. 
Rafiepour, F. (1993). Rural tendency evaluation to Jahad-e-Sazandagi. Tehran. Arganoon edition.

Rajan S Irudaya (2013), Internal Migration and Youth in India: Main Features, Trends and Emerging Challenges, Discussion paper, Commissioned by UNESCO, Centre for Development Studies (CDS), Kerala, India.

Rogaly, B., Biswas, J., Coppard, D., Rafique, A., Rana, K. and Sengupta, A. (2001) 'Seasonal Migration, Social Change and Migrants Rights, Lessons from West Bengal', Economic and Political Weekly, Vol 36, No 49, pp 4547-59
Russel King. (1978). Return migration: a neglected aspect of population geography. Area. Vol 10, No 3, pp. 175178

Sajjan, P. S. (2006). Comparative Profile Analysis of Rural Youth in Rainfed and Irrigated Tracts of Bagalkot District. M.Sc. (Ag) Thesis, University of Agricultural Sciences, Dharwad.

Smoliner, S., M. Forschner and J. Nova. (2012). Re-Turn. Comparative Report on Re-Migration Trends in Central Europe. Available at: http://www.iom.cz/files/comparative_R eport_on_Re-Migration.pdf

\section{How to cite this article:}

Parameswaranaik, J. 2019. Factors Influencing the Attitude of Return Migrated Rural Youths towards Agripreneurship Development. Int.J.Curr.Microbiol.App.Sci. 8(07): 2810-2817. doi: https://doi.org/10.20546/ijcmas.2019.807.351 